\title{
REVISITING THE STRENGTHS AND LIMITATIONS OF REGULATORY CONTRACTS IN INFRASTRUCTURE INDUSTRIES
}

\author{
Rui Cunha Marques and Sanford Berg ${ }^{1}$
}

June 25, 2009

\begin{abstract}
This paper evaluates regulation by contract in public-private partnerships (PPPs) in infrastructure services. Although the benefits of competition for the market and of regulatory contracts are widely acknowledged, the literature indentifies several failures in their design. These 'flaws' are present in both developed and developing countries and arise in all types of contracts. This study analyses both short and long term contracts, focusing on purely contractual PPPs and institutionalized PPPs (mixed companies). The evidence suggests that for all kinds of contracts, the major problems tend to arise in the preparation of public tender documents: the 'best' bidder is not often the winner. The likely results include redistribution in favor of the private partner, weak incentives for high performance, and renegotiation of contracts. Moreover, risks are not allocated correctly nor is effective monitoring ensured. This review of contract procedures and design allows us to draw several implications for policy-makers and to present suggestions and recommendations for improving regulatory contracts.
\end{abstract}

Keywords: regulation by contract; bidding documents; contract design; risk; monitoring

\section{INTRODUCTION}

Most infrastructure services are characterized by their (natural) monopolistic features, so, in theory, a single operator would maximize productive efficiency. However, actual experience suggests that prices are set above marginal and average costs, reducing economic welfare and often causing excessive profits and significant allocative inefficiency. From another point of view, the monopolistic operator often does not focus on cost reduction, as it is prone to the 'quiet life' and associated X-inefficiency. Implementing external regulation by an independent agency attempts to solve these monopoly problems, inducing optimal (or at least second best) prices and quantities, improving social welfare.

Of course, external regulation also has diverse shortcomings, including problems with asymmetric information, short-run cost containment, possibility of regulatory capture, long-run investment incentives, and regulatory opportunism. These circumstances have caused economists to seek alternative approaches for addressing (natural) monopoly problems. One approach replaces the external regulator with regulation by contract where there is competition for the 'franchise' (access to the market). This framework,

\footnotetext{
${ }^{1}$ This article was written when the first author was a Visiting Scholar in the Public Utility Research Center (PURC) at the University of Florida. The author gratefully acknowledges his sabbatical scholarship granted by the Portuguese Foundation for Science and Technology. The first author is an Assistant Professor of Systems and Management (IST) at the Technical University of Lisbon. The coauthor is a Distinguished Service Professor in Economics at the University of Florida (and PURC Director of Water Studies).
} 
utilizes public-private partnerships (henceforth PPPs). ${ }^{2,3}$ The European Union, without a formal definition of PPP, refers to it as types of cooperation between public authorities and the world of businesses aimed at ensuring the funding, construction, renewal, management and/or maintenance of infrastructure, or the provision of a related service. In a broader sense, regulation by contract integrates the setting of duties and rights of a private firm and a public partner, establishing the incentives and responsibilities under which they would operate, including the risk sharing and risk allocation (Klein, 1998).

The idea of PPP contracts has a long history. In the $19^{\text {th }}$ century in England, Sir Edwin Chadwick suggested a solution for the natural monopoly problem based on franchising (Chadwick, 1859). He distinguished between competition within the field and competition for the field. The latter was to take place when the former was not possible. The implication of this theory was that the right to operate a monopoly could be subject to an auction. The auction winner would be the bidder to present the best offer (lower price to customers or higher rent to the awarding agency). The competition which was promoted would place prices of products and services close to average costs if this was the only award criteria considered. These principles, utilized prior to the beginning of the $20^{\text {th }}$ century in Europe and the US for the provision of infrastructure services (energy, water and fixed telecoms), were re-visited and extended by Harold Demsetz. This author went farther than Chadwick by criticizing what had become cost of service regulation in the US Arguing that welfare was not maximized under arrangements utilized at that time, he identified the franchising option as the preferred approach (Demsetz, 1968).

According to Demsetz, potential competition for the market would lead to greater production and allocative (pricing) efficiency, since those bidding for monopolistic operations would feel threatened by the prices proposed by other potential competitors. ${ }^{4}$ Thus, they would set prices close to average costs, which would cover the costs entirely and allow for a reasonable and fair return on capital. Demsetz (1968, p. 61), like Chadwick, argued that the Government should auction the right to provide infrastructure services, believing that rivalry of the open marketplace (the invisible hand) disciplines more effectively than the regulatory processes of the government agencies (the visible clenched fist).

The bidding should be open with several bids and the price should be the award criteria. The bidder with the best offer (lower price or higher rent) would win the auction,

\footnotetext{
2 The concept of public-private partnership (PPP) adopted here corresponds to one used in the European Union, which includes institutionalized PPP (mixed companies) and purely contractual PPPs. The latter comprises concession, affermage, or management contracts. Concession contracts are, in its turn, divided into public work or public service concessions depending on whether the turnover of the private sector is predominantly originated in public works or in the operation of a service. The Build-Own-OperateTransfer (BOOT), Build-Operate-Transfer (BOT) and other similar contracts (e.g. DBOOT) are included in the first group. However, outright divesture (full privatization) is not a PPP. Economically speaking, the term franchising is often utilized. This paper uses the terms franchising and PPP interchangeably.

${ }^{3}$ It should be stressed that a public tender is not always required. Contractual regulation can be implemented with a wholly publicly-owned management entity (incorporated or not) as well. Frequently this occurs when the partners are public but belong to different levels of government (local and regional), called, in this case, public-public partnerships. In this review, we always assume a private partner and the existence of a public tender to award the project.

${ }^{4}$ As Dnes notes (1991, p.214) 'Demsetz is a forerunner of later contestability analysis'.
} 
guaranteeing that in a situation of sufficient competition (and no collusive behavior) that the winner would offer an average price close to the average cost, allowing for fair profits. ${ }^{5}$ The role of the Government would change from being the regulator to the one responsible for the bidding process that is, making and managing the rules so that the competition for access to the market can take place in an adequate way. ${ }^{6}$ Later articles criticized the Demsetz analysis as being too simplistic, since quality of service, network expansion and upgrade, and other issues were not fully addressed. These points are developed shortly.

In the 80's and the 90's, neoliberalism and the funding requirements of capital projects for essential infrastructures drove a number of countries to privatize their infrastructure industries. In some sectors, like energy and telecommunications, full divesture was the main option, but in the water sector (water and wastewater utilities) and in transportation (roads, railways, airports and ports) the use of PPPs (particularly concession contracts) was preferred. This happened for different reasons, but the most important is related to the responsibility for these services, which in the latter case often belongs to the municipalities, generally are close to customers, and reflect the public nature of the services. Although the impact of private sector participation in infrastructure industries is mostly positive, there are mixed results in some countries and even with seemingly successful outcomes, the results are not transparent: the results could be different. Estache (2006) stresses that in developing countries, much of what is going on is not known: "many of the fights and 'peace treaties' made by the 'partners' are not shared with the outsiders." 7

In the water and transportation sectors, some contracts had early termination and many others were renegotiated. Guasch (2004) found that for Latin America (with a sample of 1,000 contracts) $75 \%$ of the water concession contracts were renegotiated after an average of 1,6 years after their signature. The numbers are better for the transportation sector (55\% and 3.1 years) but still suggest significant flaws in initial arrangements. ${ }^{8}$ Besides the breakdown and the early termination of the contracts, renegotiation represents another major disappointing outcome for concession contracts. Under renegotiation, there is bilateral bargaining to restore a mutually acceptable situation for the parties; however, without competitive options, the operator will always have more information on the implications of alternative contractual arrangements. Thus, service providers tend to be in a position to impose their requirements. ${ }^{9}$ Such changes in the rules of the game undermine the legitimacy of the original contract award.

\footnotetext{
${ }^{5}$ As Demsetz states (1968, p.57) 'if the number of bidders is large or if, for other reasons, collusion among them is impractical, the contracted price can be very close to per-unit production cost'.

${ }^{6}$ In recognition of the contribution of Edwin Chadwick and Harold Demsetz, competition in franchise bidding, whose single factor in awarding is the price, became known as Chadwick-Demsetz auctions.

${ }^{7}$ Estache (2006) argues that the different interpretations of the success or failure of PPPs in developing countries is due to the "differences in the assessment criteria used to assess the incremental effect of reforms. ” (p. 3) The present paper does not address the distributional impact of PPPs, corruption, macroeconomic shocks, and other issues he explores, but focuses on risk allocation and contract design. ${ }^{8}$ According to past research, a higher incidence of renegotiation occurs under competitive bidding, price cap regulation, the non-existence of a regulatory body, compulsory investments, and when award criteria are based on the lowest tariff and the legal framework is embedded only in the contract (Guasch, 2004).

${ }^{9}$ As Bajari et al. (2005) shows empirically, renegotiation unavoidability leads to extra costs for users.
} 
The two major causes for the failures of PPPs are contractual incompleteness and imperfect allocation of risks. These two problems result from (what tends to be) a very simplistic bidding process, inadequate specification of the terms and conditions for the operator, incompetent oversight, and (in some cases) opportunistic behavior by powerful international corporations. This set of factors lead to dubious award granting processes, incomplete contract designs and unfair (and inefficient) risk allocation. The purpose of this study is to examine these issues and this kind of 'regulation without regulator'. This paper is organized as follows. Section 2 discusses the benefits and shortcomings of regulation by contract. Section 3 analyses the different kinds of contract depending on their possible extension and the possibility of ex-post opportunism. In addition, the study evaluates their application in infrastructure services. Section 4 examines the major failures of regulatory contracts. Section 5 analyzes briefly the different ways of private sector participation and consequently their contractual arrangements. Concluding observations are presented in section 6 .

\section{CHARACTERISTICS OF REGULATION BY CONTRACT}

\subsection{Strengths of Regulation by Contract}

The defenders of PPPs and "regulation by contract" emphasize several advantages of this option (see, for example, Demsetz, 1968, Stigler, 1968 and Posner, 1972). These advantages can be divided into those relative to the option of full divesture and relative to the alternative of public provision. Compared with the divesture/privatization option, one of the benefits of regulation by contract is that the Government does not need very detailed information about costs, demand and other features of the projects, nor is a "traditional" regulatory agency or a contractual management agency required, leading to lower cost compared with external regulation and its associated bureaucratic procedures and reporting requirements (Viscusi, et al., 1995). Another benefit is that concession and other PPP contracts do not foster over-investment compared with some regulatory methods (e.g. Averch-Johnson overcapitalization under rate of return regulation). Since the PPP-holder captures all the gains associated with efficiency improvements and new service introductions, it has strong incentives to be innovative. ${ }^{10}$ From this perspective, competition for the market yields very positive results as well, eliminating a substantial part of the monopoly rents. Other advantages are related to the operator's concern with its reputation: recognizing potential cash flows for future periods (and for other franchise areas) constrains the potential operator hold-up behavior. In theory, the operator has an interest in delivering mutually beneficial outcomes via its current operations if it intends to remain in the market after the contract expires (or to avoid early termination) and plans to expand its activities by winning other bids.

PPPs have other advantages, related to price signals and investment. Crew and Zupan, (1990) provide some theoretical explanations for reduced cross-subsidization. Indeed, in the contract arrangement, the bidders have an added predisposition to establish prices oriented to the true costs (the prices are closer to the average cost of each product and service). Analysts are familiar with traditional concerns over public provision. These

\footnotetext{
${ }^{10}$ Under some scenarios, a PPP fosters the same incentives as a pure price cap method (Crew and Zupan, 1990).
} 
emerge from public choice theory and include the agency problem, the lack of shareholder pressure (and reduced incentives for cost-containment), and lack of competitive pressures for quality improvements. The PPP option has other advantages associated with project financing, and the on-time and on-budget delivery when investors face penalties for construction delays and cost over-runs (Murphy, 2008 and Vining and Boardman, 2008). The private partner is interested in the timing of cashflows: minimizing or delaying outlays and accelerating inflows. Allocating appropriate risks to private investors (and managers) in the PPP leads to the development of risk mitigation strategies, cost savings, and service quality improvements.

In particular, the private sector is in a position to mitigate risks associated with construction and operations: such savings can reduce the NPV of project costs even in the presence of a higher risk premium (higher cost of capital). The cost savings occur over the entire project cycle, allowing for optimizing behavior throughout the stages of the project (design, construction, operation, and closure/clean-up). In general, PPPs enhance the quality of service since providers are accountable to both customers and to government partners. In addition, customers tend to be more demanding when the provider of the infrastructure services is private (Marques and Levy, 2006). When a private operator profits from the provision of an essential service, customers have higher expectations than in a situation of public (in-house) provision.

\subsection{Limitations of Regulation by Contract}

The drawbacks of regulation by contract have been identified by the opponents of PPPs and supporters of both full divesture and of public ownership. Williamson (1976) and Goldberg (1976) ${ }^{11}$ argue that information requirements are high as well. Moreover, the supervising entity responsible for contract management is basically a regulator. Thus, the cost of regulation by contract is also significant: over-investment can continue to be relevant (via the imposition of minimum investments) and the provision of incentives to efficiency and innovation is dubious (when renegotiation and ex-post opportunism, including clawbacks, play a role). ${ }^{12}$ An example of the bid preparation cost is the concession of water services in Buenos Aires in Argentina: Government bid preparation and evaluation cost about \$ 4 million (US) for and it cost each bidder about \$ 5 million (US) to prepare the bid. In addition, the bidding stage took about two years (Jouravlev, 2000, p.20). Another shortcoming is the price which is only a 'second best' (when average and not marginal prices are used). However, in theory, efficient price signals can be achieved if a two-part tariff is adopted. ${ }^{13}$

Another issue associated with regulation by contract is the principal's behavior at various stages of access to the market: the bidding stage (since the decision to call for a

\footnotetext{
${ }^{11}$ In 1907, the major problems of contractual regulation and competition for the market had already been pointed out [(Fisher, 1907), op. cit. at Williamson, 1976)].

12 One can argue that whereas 'many of the problems associated with regulation lie in what is being regulated, not in the act of regulation itself' (Goldberg, 1976, p.246), the major problems of contractual regulation are almost always related to the quality of contract design.

${ }^{13}$ If Government has sufficient information about demand, two-part price setting can be efficient (Willig, 1978). Of course, the distribution of demand and consumer surplus extracted from low-income demanders (via a monthly fee) raises issues of fairness.
} 
tender is essentially political in nature), the preparation of the documents for the bidding process, the evaluation stage, the actual award decision and announcement, the design of the contract terms, and the appeal and eventual lawsuit. The complexity of the award process is particularly relevant when there is more than one criterion, mainly when technical and quality criteria are included, often resulting in the evaluation team having some discretion (Williamson, 1976). Even if there is a single criterion, transparency and objectivity cannot be guaranteed. For example, in transportation, the use of nonstandardized (traffic) demand or in the water sector the lack of consumption pattern information (related to assumptions about the population and consumption per customer) can lead to a excessive optimism or even the winner's curse. ${ }^{14}$

Collusive behavior is another possible problem. Sometimes, there are few bidding companies, especially when the PPP contracts are divided by region. Alternatively, local reputation and regional economies of scale could cause such focused bidding (Boardman and Vining, 2008). Concerning contract monitoring, supervising quality of service requires expertise and careful auditing procedures for company-provided data. Since infrastructure services are often heterogeneous, their value depends on the customers with a willingness to pay according to the quality provided. Therefore, performance evaluation could go beyond price considerations to include the pattern of service quality provided. Quality conditions must be imposed in the bidding requirements. The government, as contracting agent, can adopt two different ways to incorporate service quality: (1) set minimum quality requirements for the bid, and (2) include the quality of service as an award criterion (adding complexity and potential discretion to the award procedure). Both methodologies require information about customer valuations of service quality and present difficulties in monitoring performance during the contract. The supervision of quality of service requires some agency to track outcomes, which reintroduces a regulator through the back door. Furthermore, governments frequently engage in rent seeking activity, which can run counter to social welfare. Side-payments or political contributions can influence initially the selection and renegotiation. In addition to the associated corruption, which is not examined here, cash-flows from PPPs can be used to subsidize other projects, endangering their viability. ${ }^{15}$

Opposition to private sector participation in the provision of infrastructure services also reflects public perceptions regarding a number of potential impacts:

1. Higher costs resulting from the search for profits;

2. Higher cost of project finance;

3. Potentially higher procurement costs (in the absence of stringent ring fencing);

4. Lower customer satisfaction (due to reduced service quality for items not stated in the contract);

5. Underinvestment in maintaining infrastructure which may lead to long term dilapidation of the network (Johnson, 1989);

\footnotetext{
${ }^{14}$ Of course, low-balling (underpricing) can be carried out deliberality in the hope of achieving more favorable terms at the contract renegotiation stage.

${ }^{15}$ For more about corruption in public contracting see Boehm and Olays (2006). These authors present hypotheses regarding corruption at three stages: 1 ) before bidding (the preparatory phase); 2) bidding and award; and 3) the aftermath (after the award).
} 
6. Threats to workers' rights;

7. Loss of public policy flexibility with a long term contract;

8. Less transparency and the accountability of the providers.

With exception of the first arguments regarding the costs (that are balanced by the reduction of costs in other items), all the other issues can be covered in the contract design. For example, concern over the rights of workers is not applicable, as most of the PPP workers are protected by law in each country. Normally, conditions for high performing workers are improved with the entrance of the private sector (e.g. new benefits, safety programs, capacity building initiatives, and rewards for high performance). Concerning accountability, although the private sector can be designated to provide infrastructure services, the responsibility for monitoring performance remains with the public sector. ${ }^{16}$

\section{CONTRACT DESIGN ISSUES}

\subsection{Classification of Contracts}

Designing PPP contracts to be signed between the Government and the private operator requires that several problems are addressed. The main issue is balancing the initial preparation costs (affecting the incompleteness of the contract) against the transaction costs generated by probable renegotiation. First, the contents of the contract must reflect the winning bid. The authors of this study argue that the template for the contract (including fixed and open clauses) should be provided as an annex in the tender documents. Only in this way can transparency and fairness be guaranteed. However, there are some clauses which require some bargaining with the winning bidder before the signing of the contract. To begin with, the activities of the (current) public operator do not stop at the moment of the tender call notice, so conditions may have changed, including alterations in the construction of some infrastructure; such changes can affect the business case. Likewise, some points are normally negotiated in this phase, including the final terms of the economic and financial arrangements, the timing of investments, specific penalties for noncompliance by both parties, implementation of procedures (including appeals), service quality levels, and conditions for early termination of the contract.

Moreover, the future is always uncertain: asset transfer between contracts can introduce controversy into the process (Posner, 1972). If prices, production technology, and demand are known in advance or do not change over time, the cash flows will be predictable. Similarly, if the contract only encompasses operation and maintenance and does not include the investment in sunk and long-lived assets, the relationship between the government and the private firm presents few contractual issues. Such contracts can be classified into two groups: (1) short-run with systematic biddings (rebidding) between one and five years, possibly up to 10 years, and (2) incomplete and long-run contracts with a length greater than twelve years (Klein, 1998). The literature diverges

\footnotetext{
${ }^{16}$ Some authors consider a perceived lack of accountability an advantage since private firms can set prices that reflect the true cost of service (Vining and Boardman, 2008). Although this point of view is understandable, the public sector cannot dismiss its own responsibility. As Hart (2003) notes, 'the owner has 'residual control rights'.
} 
between the defenders of one and other kind. Stigler (1968) advocated a third approach of contracts, the so-called 'once-for-all contracts' which, realistically are not viable in most infrastructure services. The strengths and limitations of different types of contracts are discussed and analyzed next. ${ }^{17}$

\subsection{Rebidding and Short-Run Contracts}

Short-run contracts present two major advantages. First, the detail and the specification about costs and demand, as well as the possible flaws in arrangements are not excessively problematic since the contracts are periodically reviewed in the new public bidding. Thus, deviations from mutually beneficial arrangements are not significant. Second, these contracts do not need to focus on quality of service supervision due to the short time frame. If the operator causes trouble or provides poor service quality a new contract or extension can be rejected. Thus, the operators, a priori, are not 'fly-by-night service providers': they intend to continue to operate in the market and will take care to fulfill the contract, maintain good relationships with customers, and strengthen their reputation.

On the other hand, short-run contracts may exhibit shortcoming related to the renewal of the contract. These problems are based on the lack of parity among bidders, reflecting information asymmetries. The incumbent will generally have made investments in infrastructures in the service territory and will have a deep understanding of demand patterns and local geography. Although assets can be transferred to a new entrant, this process is not simple. The initial operator was presumably maximizing profits, so book value (after depreciation) may not correspond to the economic value of assets, especially when maintenance of underground networks is difficult to verify (Williamson, 1976). The workers who have technological know-how of operations are not necessarily easy to transfer. Such shifts in operators are likely to involve higher salaries (although if the local market for such specialized skills is thin, this may not be such a problem).

Another advantage for the incumbent is the inertia of politicians and bureaucratic decision makers, who are likely to be unenthusiastic about starting a new contractual relationship. Potential changes in working methods and routines tend to reduce the likelihood of switching providers when the selection gives decision-makers discretion (Viscusi et al., 1995, p.426). Thus, the incumbent's knowledge of about future demand, organizational capabilities, and the true cost of production give it an advantage over other bidders. In a careful study of more than 3,000 decisions on renewal of cable TV contracts in the US, only sixty of them involved replacing the incumbent. However, the authors could not determine whether the stability was related to the lack of competition or to satisfaction with incumbent performance (Zupan, 1989 a, b). Finally, short-run contracts are viewed as hindering efficiency and innovation, since there is no guarantee if investors can take advantage of savings from capital outlays on long-lived assets.

\footnotetext{
17 The contractual issues are analyzed in detail in two seminal articles that advocate and criticize the regulation by contract, respectively. See Posner (1972) and Williamson (1976).
} 


\subsection{Incompleteness and Long-Run Contracts}

Long term contracts are labeled as incomplete since they are unable to specify responsibilities under all possible contingencies. Responsibilities tend to be negotiated over the time through rules and understandings that emerged in response to similar events in the past. The main advantage of this kind of contract is its appropriateness when it is necessary to make large investments in long-lived (sunk) infrastructure networks, where the payback period is relatively long. The drawbacks that are usually highlighted include (a) higher risks associated with these contracts, (b) difficulty of designing terms and conditions that are mutually beneficial, (c) greater transaction costs than short term contracts, (d) the need to predict the maximum change for automatic mechanisms related to the consumer price index (annual review of tariffs), and (e) the inclusion of rewards and penalties according to overall performance and the fulfillment of specific contract clauses. ${ }^{18}$

\subsection{Opportunism Ex Post $^{19}$}

Opportunistic behavior ex post can be exhibited by the winning bidder (private partner) or the awarding entity (public partner). On the one hand, the private firm might want to renegotiate the contract, based on the clauses agreed upon ex ante, arguing that the demand is lower and the costs are higher than predicted and that there are exogenous factors which change the contractual conditions defined ex ante. This process of renegotiation is long and complex and enables deviations from the original contract, so objectives of the project may not be achieved. The choice of the PPP-holder is made by public tender (competitive environment) and the renegotiation is a bilateral bargain. Thus, there are substantial information (and resource) asymmetries (see Guasch, 2004). ${ }^{20}$

One strategy of players in public biddings is "low balling": submitting a bid with an exceptional quality and very low prices, perhaps not even covering reasonable average cost. Such underbidding intentionally involves the (optimistic) winner's curse: the winner then is betting that renegotiation will result in a profitable outcome (Dnes, 1995). Thus, the operator has a margin for bargaining, assuming that some kind of investment has already been made. The threat of interruption in the provision of a service that is essential to the current customers and to society over time constitutes one tool the operator has to put pressure on the government. However, that strategy opens up the possibility of strong retaliation by the state or the municipality and loss of reputation for the current operator (Zupan, 1989b).

\footnotetext{
${ }^{18}$ Littlechild (2002) analyzes with great detail the PPP contract of the subway in London, which is a long -run contract. The contract took 3 years to be signed, cost about 15 million pounds and included about 2,500 pages of documentation whereas the Electricity Act, which regulated the full privatization in the UK, comprised 214 pages. Due to several reasons the PPP contract was broken recently.

${ }_{19}$ Oliver Williamson notably refers to the opportunism as the 'self-interest seeking with guile' (Williamson, 1985, p.47)

${ }^{20}$ According to Engel et al. (1997, p.9) 'the problem with renegotiations is that they replace the ex ante competition of competitive auctions with an ex post bilateral monopoly, in which the Government [i.e. the taxpayer] usually ends up worse off. Moreover, the results of renegotiation can easily lead to charges of corruption and discretion, which has perverse effects on the participants in future franchises'.
} 
At the same time, the government can take advantage of the fact that the operator will have made large infrastructure investments, which are long-lived and sunk, so that maximum prices can be kept close to average cost by rejecting renegotiation. If the operator underbid in order to be in a position to renegotiate or if there were flaws in the bid design, the "winner" is likely to experience serious financial strains. The investments made and its reputation, even with anticipated losses, can compel the operator to remain in the market.

Thus, the awarding entity has several tools to control the opportunistic behavior of the private firm, including:

- The possibility of renegotiation of the contract with the operator that, at least in the final stage of the contract, curbs its opportunistic behavior;

- The existence of clauses which penalize these behaviors;

- The decisions to be taken on the issues open for negotiation by the contract (which, by definition, is incomplete);

- The impact on the operator's reputation or that of other governmental entities;

- The threat of early termination of the contract.

When both parties to the contract have options for improving their positions at the expense of the other, disputes are likely to arise.

\subsection{PPPs and Evaluation of Regulation by Contract}

PPP contracts, especially those that are long term, are inevitably incomplete and are accompanied with large uncertainties, increasing the risks facing both parties. The awarding entity must devote resources to monitoring the contract (Williamson, 1976). Likely renegotiation of the contract, uncertainty about the future, supervision of service quality, and the application of sanctions transforms the role of the awarding authority (originally responsible for contract management) into someone with similar functions to a traditional (external) regulator. Regulatory functions do not disappear, whether the contract is short term or long term in nature.

Furthermore, regulation by contract is more effective in industries that do not require capital intensive, long-lived investments. Such sunk investments require payments for the economic value of investments, complicating their transfer between those winning bids in two consecutive periods (see Vickers and Yarrow, 1989, p.111, Armstrong et al., 1994, p.129 and Baldwin and Cave, 1999, p.268). Some authors even argue that PPPs and regulation by contract should not be used in the network sectors like water, energy and telecoms. ${ }^{21}$ Engel et al. (1997) add that PPPs should also not be used in sectors where the quality and maintenance of assets cannot be easily attested to by an external entity, for example where there are buried infrastructures which correspond to a significant portion of assets. Klein and Roger (1995) argue that regulation by contract should only be applied when the investments are not specific for a particular area and therefore they are not sunk. These academic views have not convinced policy decision-

\footnotetext{
${ }^{21}$ Vickers and Yarrow (1989, p.111) wrote 'there are many industries where franchising cannot work, at any rate in this simple form, and in the industries described later in this book (energy, telecommunications, water, etc.) provide leading examples'.
} 
makers in the water sector, for example, since the introduction of the private sector is generally done by means of PPPs and regulation by contract.

In a practical sense, unlike the ideal circumstance (e.g. when the price is the only award criterion, contracts are short term, and there are many capable, competitive bidders), the requirements of PPPs and regulation by contract are similar to those associated with external regulation by an autonomous agency. As such, we argue that regulation is both necessary and unavoidable. However, the benefits of competition for the market and regulation by contract can be relevant when governments seek private sector participation. Indeed, it is impossible to design long term contracts that are sufficiently complete and definitive (covering all potentially significant contingencies) and that are invulnerable to ex post opportunism.

Thus, a possible solution utilized in many countries involves combining regulation by contract with external regulation, where the sector regulator is independent from the awarding authority (Marques and Monteiro, 2002). In the sequencing of the award, it is useful to have the sector regulator responsible for providing expertise in the public tender stage. In addition, it should have the authority to monitor service quality, apply penalties for non-compliance with the contract, serve as arbiter in dispute resolution proceedings, and assist in mediating any contract renegotiation. This set of roles, despite the associated costs, combines most of the advantages of regulation by contract while mitigating potential problems through the monitoring activity of an external agency (regulator).

\section{THE FAILURES OF CONTRACTS}

\subsection{Access to the Market}

One of the major advantages of regulation by contract and of PPPs is that in most situations the government uses the market prices (bids) to choose the private partner. To award a PPP, at least in the European Union, a public tender is compulsory and the rule is to choose the most economically advantageous bid. When only one criterion exists, normally the price (e.g. average tariff or toll), the rent paid, or the net present value, the winning bidder corresponds straightforwardly to the bid which presents the lowest price (or highest value). However, when there are several criteria, the situation is more complicated and it is necessary to apply multi-criteria decision analysis to choose the winner. In this case the awarding party should define the criteria (and eventually subcriteria) and the bid assessment methodology before the tender call notice.

This methodology should be provided in the public tender documents and should be based on three major principles: (1) ensuring comparability among bidders (meeting some minimum organizational standards), (2) keeping the rules initially established and provided to the competitors before presenting their bids, and (3) evaluating only the essential factors, including the delineation of appropriate risk sharing (avoiding consideration of superficial elements). Also, when there is a two-stage bidding system, 
in the second stage the evaluation criteria should be the same as in the first one, and only the players in the short-list can improve their initial bids. ${ }^{22}$

Note that previous experience and financial health of the bidders should be qualification criteria and not part of the bid evaluation process. Criteria which allow for discretion, like quality of service or safety, should be avoided. These should be pre-specified. If they can differ across bids, such elements are difficult to evaluate, increase the price associated with the bids and have a reduced value since they change over time and normally a PPP encompasses the long term. In addition, the authors think that in essential services like those provided by water and electricity utilities, the quality of service and the safety should be imposed, not negotiated. Of course, if bidders are likely to have widely different capabilities for meeting technical quality standards (and these are negatively correlated with other cost determinants), two quality standards might be set, letting the bidders make separate bids under each standard. Then the award could be made to the bidder with the "best" option, recognizing that such a system introduces some discretion into the process.

Typically, PPPs establish dozens of subcriteria with substantial detail. Such elements are likely to be useless, and worse, damaging of the public interest by increasing the complexity of the evaluations and the cost of bid preparation. For the purpose of the bidding stage, all the variables should be standardized to increase the comparability of the bids. If a net present value of a bid is derived using a different discount rate from another bid, the values are not comparable. The same screening should be done for population projections, annual consumption patterns, peak demand forecasts and other variables. Note that this standardization is only for evaluating the bids; otherwise, the awarding entity would have to assume the associated renegotiation risks. For example, demand forecast is one of the most important determinants of cash flows (and the probability distributions for the forecast affect the discount rate). Of course, different assumptions by various bidders would have led to different bids, but when such capital intensive projects are under consideration, awarding the project to the most optimistic bidder almost guarantees renegotiation. It is better to make the award based on outputs (e.g. population served) or on standardized inputs (e.g. construction cost estimates for a pattern of demand or pre-specified physical characteristics of network expansion).

Another relevant aspect is that evaluators should focus on what is important in a PPP contract, which is very different from traditional public procurement (e.g. public works). For example, since the probability of renegotiation is high, the elements that create valuation discrepancies should be taken into account. First, the evaluation process should conduct sensitivity analyses of the bid (business case) to adverse situations (e.g. consequences of a substantial drop in demand or in macroeconomic recession). As it was noted earlier, different assumptions adopted by each bidder in the business case can be very important. For example, two bidders may have a proposal for a similar toll in a highway but the shareholders of one of them demands a return on equity of $15 \%$ and the other requires only $10 \%$. The financial and economic equilibrium of the business case will be determined by that rate, with tolls lower (or the investment recovery period shorter) for the latter case. So, the implications of renegotiation will be very dissimilar

\footnotetext{
${ }^{22}$ The first stage sometimes corresponds to a pre-qualification stage where the technical and economic capabilities are evaluated.
} 
depending on the winning bid. Such contingencies must be incorporated into a PPP evaluation process.

Finally, it should be emphasized that the tender documents are frequently badly prepared. If more studies and information are collected (and made available) before the tender call notice, all the parties benefit (Crampes and Estache, 1998). Unfortunately, political windows of opportunity can lead to excessively short time frames for the bidding process. In such cases, the cost of supporting consulting studies, inadequate time for preparation of bidding templates, and lack of involvement of other agencies with appropriate expertise lead projects to be launched with incomplete (often inadequate) information. For example, the public sector entity on which the project is based should be analyzed prior to the preparation of bidding documents, yet such financial and operational studies are seldom carried out in advance of tending the bid. The resulting lack of public information on current operator performance increases the risk of the project (and thus, the cost of capital) and often leads to a major assumption of commercial and operating risks by the public sector.

\subsection{Managing and Sharing the Risk}

The main theoretical benefit in PPPs is that the risks would be assigned to the contractual party that is best able to mitigate the risk or to bear the risk. This allocation minimizes the economic costs associated with such risks. From this perspective, the State should not transfer the risks that are under its control to the private partner; nor should it (as it represents taxpayers) assume the risks that are out of its control. In the European Union (Eurostat), the rule is not to include the PPP's charges in the public accounts if the private sector has to support at least two of the three risks: construction risk and demand risk or availability risk. Most contracts have clauses protecting the private sector from bearing such risks while ensuring economic and financial equilibrium during the contract. If it is clear that exogenous events would lead to the contract re-negotiation, such events (and related to risks) should have been assigned to appropriate parties and carefully defined ex-ante.

The allocation of risks and the contractual clauses affecting the economic and financial equilibrium are required to avoid opportunistic behavior and to provide the value for money of the project. Figure 1 indicates how the evaluation of risks in a PPP involve a number of steps: (1) identification of risks, (2) classification of risks, (3) evaluation of their probability, (4) evaluation of their impact, and (5) identification of measures for minimizing risk (Marques and Berg, 2009).

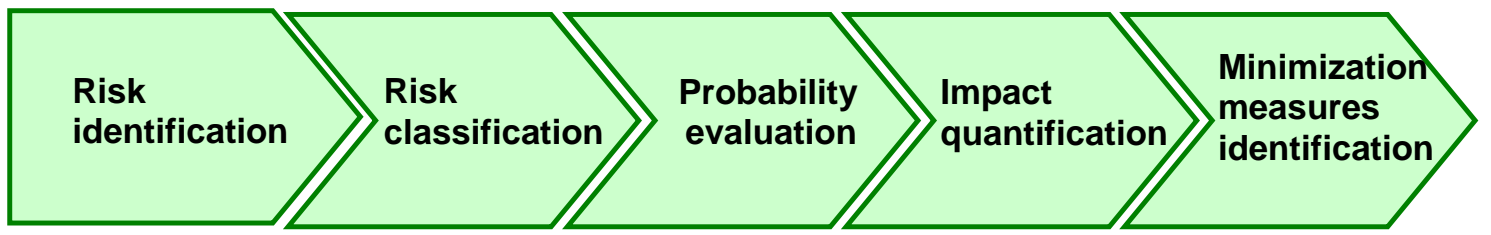

Figure 1 - Steps in Risk Evaluation

Since risk is defined as the probability of a particular event occurring, all the steps should be considered before a PPP is launched. They are particularly important to 
determine if the PPP model is the most appropriate, in terms of the alternative: a public sector comparator. ${ }^{23}$ In evaluating the PPP, the private firm should take risks based on well-designed incentives: to promote cost containment and to manage risks. Thus, it is crucial that those preparing the contract identify and allocate risks before the public tender stage. The authors suggest that a risk matrix with contractual clauses addressing each risk should be developed before opening bidding and provided to the bidders. The bidding documents should limit ex ante situations that may lead to ex post opportunism.

Risks can be divided into production, commercial and contextual risks. Some of these risks are associated with the bidding process stage and others with the project stage (Marques and Berg, 2009). While risks related to the production process are almost always best borne by the private sector, the commercial and contextual ones are mixed; unfortunately, sometimes they are transferred to the private sector. Figure 2 presents the most typical risks and classifies them according to the information above. The importance of each risk depends on the infrastructure services at stake.

\begin{tabular}{|l|c|}
\hline \multicolumn{2}{|c|}{ Production risks } \\
\hline Planning & +++ \\
\hline Conception & ++++ \\
\hline Expropriation & + \\
\hline Construction & ++++ \\
\hline Environmental & + \\
\hline Maintenance and major & +++ \\
repairs & \\
\hline Operation & +++ \\
\hline Technological & ++ \\
\hline Performance & +++ \\
\hline
\end{tabular}

\begin{tabular}{|l|c|}
\hline \multicolumn{2}{|c|}{ Commercial risks } \\
\hline Demand & +++++ \\
\hline Collection & + \\
\hline Capacity & +++ \\
\hline Competition & + \\
\hline
\end{tabular}

\begin{tabular}{|l|c|}
\hline \multicolumn{2}{|c|}{ Context risks } \\
\hline Financing & ++++ \\
\hline Inflation & ++ \\
\hline Legal & ++ \\
\hline Regulation & +++ \\
\hline Unilateral changes & +++++ \\
\hline Public contestation & ++ \\
\hline Force majeure & ++ \\
\hline
\end{tabular}

Figure 2 - Identification of Major Risks

Demand developments and unilateral changes generally have the most serious consequences for the continuation of a mutually beneficial partnership. Concerning the demand risk, often the public authority is influenced by an optimistic bias, since this allows to increase its rent in the short-term. It assumes high growth rates (unrelated to reality), justifying an unrealistically high up-front PPP payment. ${ }^{24}$ This risk can be eliminated if the contract length is variable, dependent on the observed demand and/or

\footnotetext{
${ }^{23}$ The public sector comparator is a benchmark value which represents the most efficient procurement cost to achieve the required service delivery outcomes and it is used as the baseline (sometimes as a maximum price) for assessing the potential value for money of the project. The document justifying the computation of this benchmark is compulsory in several countries and in the opinion of the authors should be provided to the bidders. For more about the public sector comparator, see Quiggin (2004).

${ }^{24}$ The up-front payment has an important benefit in the perspective of public sector, since it is seldom renegotiated (Crampes and Estache, 1998).
} 
of the corresponding revenue (Engel et al., 2001). ${ }^{25}$ The common practice is to assume that a change of demand over 10 to 20 per cent leads to a renegotiation of the economic and financial equilibrium. In such situations, demand risk is nearly completely borne by the public sector (generally passed on to the users or customers). As far as unilateral changes (political) risk is concerned, the solutions are more difficult but the contract clauses should be sufficiently deterring to avoid regime changes, mitigating them by assigning associated risks (again) to the public partner.

\subsection{Monitoring Contracts}

Monitoring the contract is equivalent (in practical terms) to the role performed by an external regulator. Indeed, the entity managing the contract has functions quite similar to those of a regulator. Maybe the greatest difference is that the "contract manager/monitor" has less discretion than a sector regulator, since some of the terms and conditions are fully specified in the contract. The major problems of monitoring are related to supervising service quality, resolving contractual disputes, applying sanctions and performance rewards, potential renegotiation and alterations of the business case (investments), early termination of the contract, asset transfer, and renewal of the PPP. Specific procedures for reporting by the PPP-holder (and the associated information quantity and quality) is important as well. Such issues should be determined prior to the contract signature and (as far as possible) included in the tender documents. Similarly, at this stage the resources required to perform contract monitoring should be predicted.

Quality of service supervision is a core issue for most infrastructure contracts. The levels of service can be embedded into the contract but they can change over time, making it necessary to monitor relevant indicators. The invisible deterioration of the infrastructures is also hard to establish. Normally, performance indicators associated with levels of service are used for this purpose; data are used for comparisons. The resulting public discussion (a name and shame policy) can press the operators to improve their service quality over time. Such public disclosure of results on a regular basis is unlikely to occur under self-regulation: a data collection/reporting organization is necessary for this purpose. The role of this body is comparable to that of regulator.

The application of sanctions and dispute resolution processes are other important issues. Regarding the former, sanctions (or penalties) should be automatically applied after due diligence. In several countries, owing to the ineffective judicial system, the sanctions are never applied as since private operators avoid them though appeals. However, sanctions can put pressure on suppliers to improve performance (e.g. reducing electricity shortages or water service interruptions). If there is payment by the public partner to the private firm, the sanction can be applied directly; the same applies when the operator receives a rent from the private firm. The performance rewards can also be automatically defined in this way. Sanctions represent a tool for putting pressure on the operator. The contract is not necessarily working well if no sanctions are applied.

\footnotetext{
${ }^{25}$ These authors suggest that the award criteria should be the 'least present value of revenue' (Engel et al., 2001). Indeed, where the demand (consumption) risk is relevant, this option has great benefits.
} 
Finally, an independent body can play an important role by becoming a referee in conflict resolution processes. ${ }^{26}$

The renegotiation stage has already been discussed. A PPP contract is considered a failure if renegotiation occurs during its period of operation. Therefore, from the start, it is fundamental that both partners must be responsible for bearing and mitigating their respective risks. When the contract breaks down, resources must be spent by both partners, first before restoration of financial and economic equilibrium and after in the revision of the contract. One approach might be to formally incorporate renegotiation of the contract, for example, from 10 to 10 years or from 5 to 5 years. However, the conditions related to the internal rate of return (of project and of equity) and other financial indicators should be those initially established in the competitive and for that reason their evaluation at the tender stage is of major importance. Moreover, only the event or cause that precipitated the renegotiation should be incorporated into the new business case. Under no circumstance is it acceptable for the private sector to take advantage of renegotiation (for a particular event) and use the process to recover the losses related to risks assumed by the private partner. On the other hand, if there is a change in the investment plan required by changes in the law (as with some new environmental regulation), a separate body (external regulator) should evaluate the impact of the exogenous change on the firm.

Two other issues are the criteria for calculating associated compensation and the procedure for early termination of the contract. The appropriate compensation depends on whether the origin of the breakdown is a unilateral decision of the awarding authority or is in fact due to activities or decisions of the private firm. Procedures for addressing responsibility can be set in the contract but they are often not well-specified. Another omission is the right to receive the value of non-depreciated investments and compensation for lost profits (or damage caused) if the one responsible is the public partner. Such situations need to be addressed by an independent third entity.

Finally, the transfer of assets and their renewal are also controversial. The determination of the asset value is neither easy nor peaceful when the amount is in dispute between the public and private partners. As a result, the incumbent often continues to be the one responsible for the infrastructure service. In Europe there are private monopolies in place for longer than 100 years precisely for this reason (e.g. Águas de Valencia in Spain).

\section{MODELS OF PRIVATE PARTICIPATION}

As mentioned above, models of privatization can be classified into two major groups: contractual PPPs and institutionalized PPPs. The first one is purely contractual and includes concession, affermage (leasing) and management contracts. Contractual PPPs like BOOT or BOT models are normally included in the public works concession contracts. When the infrastructure is owned by the private sector, the public sector

\footnotetext{
${ }^{26}$ Independence is also important when the regulator is responsible for amending contracts ex post.
} 
seems to engage in less intervention. For example, such a framework is usually adopted for the construction of bridges. ${ }^{27}$ Table 1 presents key features of four arrangements.

Table 1 - Features of the Purely Contractual PPP

\begin{tabular}{lcccc}
\hline \hline \multicolumn{1}{c}{ Feature } & Management contract & Affermage & Concession & Full divesture \\
\hline Ownership & Public & Public & Public & Private \\
Assets ownership & Public & Public & Public/private & Private \\
Investment & Public & Public & Private & Private \\
Commercial risk & Public & Shared & Mainly private & Private \\
Payment & Government & Users & Users & Users \\
Duration & 3 to 8 years & 8 to 15 years & 20 to 35 years & - \\
\hline \hline
\end{tabular}

Of course, concessions can have complications, as when determining whether the project is bankable. Investor perceptions of these commercial and operating risks affect the cost of capital. Nevertheless, concession contractual PPPs have benefits to the extent that equity can be leveraged and that private participation improves incentives for high performance. Such arrangements are primarily adopted when large investments are necessary or the governments are maximizing up-front payments (rent-seeking by the principal). They are used in several sectors, particularly in the water sector and in transportation (e.g. highways and seaports).

Affermage contracts have other kind of risks. As the private firm is not responsible for new investment, its performance can be negatively affected if there is public sector underinvestment. The outcome might be low marks based on benchmarking indicators, yet the public asset owner is responsible for reported "poor" operating performance. Thus, issues of mutual accountability arise. This affermage model is employed in two different situations. This option can be utilized if the Government does not want to raise prices and commits to continuing public investments. Thus, private firms do not need to raise capital at market rates. This division of responsibilities amounts to a subsidy to customers provided by the public partner. The model reduces both the risk and potential return of the private partner. In the second situation, the amount of investment is reduced and the government intends to periodically rebid the contract. The latter is frequently prone to risk, when the government cannot fulfill investment deadlines, causing delays in infrastructure construction. The result is lower cash flows than predicted, increasing the likelihood of reduced quality in the short-run (with cutbacks in staffing) and the long-run (due to reductions in maintenance outlays). ${ }^{28}$ Furthermore, customers deal with the operator and not with the one who is responsible for investments, complicating public perceptions regarding which partner is 'blamed' for weak performance. These contracts are very popular in the water sector in France.

\footnotetext{
${ }^{27}$ In several countries, the constitution prohibits private ownership of transportation and other essential infrastructures; therefore, BOOT projects cannot be implemented.

${ }^{28}$ Governments have a natural tendency towards an 'escalation of commitment' which can actually harm the public interest (Dietz-Uhler, 1996). Examples from Japan, US, UK, India, Latin America, and Africa are presented in Berg et al. (2002).
} 
In management contracts, there is no direct relationship between the private partner and the customers. The private partner is paid by the government for performing particular tasks. Normally, management contracts are implemented in sectors such as health or education (which are heavily subsidized by taxpayers) or in the management of water and wastewater treatment plants (where revenues are unlikely to cover costs). A priori, these contracts should have a short length, but sometimes such contracts are in effect for extended periods. For example, hospital contracts in some countries can be 30 years in duration. $^{29}$

The second model of partnership is the institutionalized PPP. Here the public sector and a private company create a third company to perform an infrastructure service or an existing public company sells part of its shares to the private sector. The public sector, in general, holds the corporate control of the company although the technical management is normally carried out by the private company. Curiously, this model has been little analyzed in the literature although it is very popular in some countries (e.g. the Société d'economie mixte in France, the Stadtwerke in Germany or the Empresa Mixte in Spain). ${ }^{30}$ The few studies have diverging critiques of such arrangements. At a first glance, the model has sound principles, since sharing management responsibility can avoid some conflicts (Marra, 2007). Since the public sector is now more accountable, there is less imperfect information and the disputes can be solved internally: outcomes can improve. Participants from the public sector, primarily local public sector agents, also like the model. They hold their authority (and political power) over infrastructure services by being able to appoint the board of directors, approve major decisions, and interfere with daily management.

However, companies that are jointly owned by private shareholders and government can lead to the worst of both worlds, achieving neither high profitability nor worthwhile social goals (Boardman and Vining, 2008). The problems revolve around political, contextual, and incentive issues. Governments in power at any level seldom acknowledge or criticize their own earlier decisions. Thus, risks tend to be passed on to customers via higher rates (or taxpayers through implicit subsidies). In the contractual PPP, an arms-length relationship is established through a signed contract setting out (1) the rights and duties of the parties and (2) the financial conditions of the service, and (3) the duration of the arrangement. In institutionalized PPPs, there are only the statutes of the firm and a shareholder agreement document which regulates the relationships between the private and public partners. As the public sector is involved in management, key elements like price levels and price structures, quality of service, and investments are periodically defined. This period is initially relatively long; despite having an initial public tender for the sale of shares, it is easy for the private partner to justify cost overruns to its public peer, leading to a need for tariff changes. For this reason, the incentives to be efficient and innovative are reduced. Another problem is

\footnotetext{
${ }^{29}$ Often such contracts only include overseeing construction of the building and its maintenance. Such an approach, although adopted from the perspective of the whole life cycle of the infrastructure project, mainly aims at having fewer installment payments. This can be costly for the financing of a project as private financing is more expensive than public financing, given investor attitudes towards risk and the ability of the government to diversify across the economy and internalize some external benefits.

${ }^{30}$ Some exceptions are provided in Eckel and Vining (1985), Vining and Boardman (1989), Chui (2003), Marra (2007) and Bognetti and Robotti (2007).
} 
that frequently there are generous payments by the mixed company to the private firm for management fees; in addition, there may be payments to the mixed company or the private firm for other services provided directly to the municipality. ${ }^{31}$

\section{CONCLUDING REMARKS}

This paper evaluates regulatory contracts in PPPs for infrastructure industries. After providing an overview of the theoretical merits and shortcomings of PPPs, the paper examined actual practice for contractual PPPs and institutionalized PPPs (mixed companies). The ideas behind PPPs are sound: the spread of this public procurement model is justified in principle. However, PPPs (as implemented) often have problems related to the design and incompleteness of contracts which, as rule, start when the public tender documents are developed and distributed. The effectiveness of contracts depends on a number of characteristics, including conditions affecting their likely extension, the balance between short term contract rebidding and incompleteness associated with longer term contracts, and how effectively the contract constrains opportunism ex post. Despite well-documented problems, both contractual and mixed company PPPs are widely utilized in the delivery of infrastructure services. The major explanation for this is associated with financing, which unfortunately is a politically powerful driver, even if the economic consequences can be problematic in the long term. Here, regulatory contracts are analyzed in terms of access to the market, approaches to risk sharing, and contract monitoring. Failures in any of these areas can result in a PPP not meeting citizen expectations. We present several recommendations and underscore the need for better preparation of PPP public tenders, both in terms of preliminary studies and the design of the bidding documents. Outcomes can be improved by giving greater attention to risk allocation, reducing the role of discretion when formalizing award criteria, and establishing credible procedures for monitoring performance.

\section{REFERENCES}

Armstrong, M.; Cowan, S.; Vickers, J. (1994). Regulatory Reform: Economic Analysis and British Experience. The MIT Press, Cambridge.

Bajari, P.; Houghton, S.; Tadelis, S. (2006). Bidding for Incomplete Contracts: an Empirical Analysis, Working Paper, no, 12051, NBER.

Baldwin, R.; Cave, M. (1999). Understanding Regulation: Theory, Strategy and Practice. Oxford University Press, Oxford.

Berg, S.; Pollitt, M.; Tsuji, M. eds. (2002). Private Initiatives in Infrastructure: Priorities, Incentives, and Performance. Edward Elgar, Cheltenham, UK. xii-233.

\footnotetext{
${ }^{31}$ Frequently these 'benefits' are not evaluated in the public tender stage despite their being a very relevant part of the project. For example, in Portuguese water and wastewater mixed companies it is usually the municipality that directly awards the stormwater service to the private sector. As this service is rarely directly paid for by customers, the municipality can end up paying an excessive fee for associated services.
} 
Boardman, A.; Vining, A. (1989). Ownership and performance in competitive environments: a comparison of the performance of private, mixed, and State-owned enterprises. Journal of Law and Economics, Vol. 32, no. 1, pp. 1-33.

Boehm, F.; Olaya, J. (2006). Corruption in public contracting auctions: the role of transparency in bidding processes. Annals of Public and Cooperative Economics. Vol. 77, no. 4, pp. 431-452.

Bognetti, G.; Robotti, L. (2006). The provision of local public services through mixed enterprises: The Italian case. Annals of Public and Cooperative Economics. Vol. 78, no. 3, pp. 415-437.

Chadwick, E. (1859). Results of different principles of legislation and administration in Europe: of competition for the field, as compared with the competition within the field of service. Journal of the Royal Statistical Society. Vol. 22A, pp. 381-420.

Chui, Y. (2003). Estimating the cost efficiency of mixed enterprises in Taiwan. International Journal of Management, Vol. 20, no. pp. 81-87.

Crampes, C.; Estache, A. (1998). Regulatory trade-offs in the design of concession contracts. Utilities Policy, Vol. 7, no. 1, pp. 1-13

Crew, M.; Zupan, M. (1990). Franchise bidding for public utilities revisited. In Competition and the Regulation of Utilities. Ed. by M. Crew. Kluwer Academic Publishers, Boston, pp. 173-188.

Demsetz, H. (1968a). Why regulate utilities? Journal of Law and Economics. Vol. 11, no. 1, pp. 55-65.

Dietz-Uhler, B. (1996). The escalation of commitment in political decision-making groups: a social identity approach. European Journal of Social Psychology, Vol. 26, no. 4, pp. 611-629

Dnes, A. (1991). Franchising, natural monopoly, and privatization. In Regulators and the Market: an Assessment of the Growth of Regulation in the UK. Ed. by C. Veljanovski. Institute of Economic Affairs, London. pp. 210-133.

Dnes, A. (1995). Franchising and privatization. Public Policy for the Private Sector. Note no. 40, World Bank, Washington, D. C.

Eckel, C.; Vining, A. (1985). Elements of a theory of mixed enterprise. Scottish Journal of Political Economy, Vol. 32, no. 2, pp. 82-94.

Engel, E.; Fischer, R.; Galetovic, A. (2001). Least-present-value-of-revenue auctions and highway franchising. Journal of Political Economy. Vol. 109, no. 5, pp. 9931020

Engel, E.; Fisher, R.; Galetovic, A. (1997). Revenue-based auctions and unbundling infrastructure franchises. Infrastructure and Financial Markets Publication, no. 112. Inter-American Development Bank. Washington D. C.

Estache, A. (2006). PPI partnerships vs. PPI divorces in LDCs. Review of Industrial Organization, Vol. 29, no. 1, pp.3-26.

Fisher, W. (1907). The American municipality. In Commission on public ownership and operation. Municipal and Private Operation in Public Utilities. Part I, Vol. 1. New York, pp. 36-48.

Goldberg, V. (1976). Regulation and administered contracts. The Bell Journal of Economics. Vol. 7, no. 2, pp. 426-448.

Guasch, J. (2004). Granting and Renegotiating Infrastructure Concessions Doing It Right. World Bank, Washington, D.C.

Hart, O. (2003). Incomplete contract and public ownership: remarks, and an application to public-private partnerships. The Economic Journal, Vol. 113, pp. 69-76. 
Johnson, L. (1989). Price Cap Regulation in Telecommunications Regulatory Reform. Markle Foundation, Santa Monica.

Jouravlev, A. (2000). Water Utility Regulation: Issues and Options for Latin America and the Caribbean. Economic Commission for Latin America and the Caribbean (ECLAC), Santiago do Chile.

Klein, M. (1998). Klein, M., 1998. Bidding for concessions. World Bank Policy Research Working Paper no. 1957, World Bank, Washington D. C.

Klein, M.; Roger, N. (1995). Back to the future: the potential in infrastructure privatization. In Finance and the International Economy: 8. Ed. by R. O’Brien. Oxford University Press, Oxford, pp. 42-68.

Littlechild, S. (2002). Competitive bidding for a long-term electricity distribution contract. Review of Network Economics. Vol. I, no. 1, pp. 1-38.

Mara, A. (2007). Internal regulation by mixed enterprises: the case of the Italian water sector. Annals of Public and Cooperative Economics. Vol. 78, no. 2, pp. 245-275.

Marques, R.; Berg, S. (2009). Risk and contracts: a methodological approach. Mimeo.

Marques, R.; Levy, J. (2006). A Qualidade dos Serviços de Água e de Aguas Residuais. $O$ Parecer do Consumidor. Associação das Empresas Portuguesas para o Sector do Ambiente (AEPSA), Lisbon.

Marques, R.; Monteiro, A. (2002). A regulação dos serviços de abastecimento de água e de saneamento. Águas \& Resíduos, Série II, no. 2, pp. 10-20.

Murphy, T. (2008). The case for public-private partnerships in infrastructure Canadian Public Administration. Vol. 51, no. 1, pp. 99-126.

Posner, R. (1972). The appropriate scope of regulation in the cable television industry. Bell Journal of Economics and Management Science. Vol. 3, no. 1, pp. 98-129.

Quiggin, J. (2004). Risk, PPPs and the public sector comparator. Australian Accounting Review. Vol. 14, no. 2, pp. 51-61.

Stigler, G. (1968). The Organization of Industry. University of Chicago Press, Chicago.

Vickers, J.; Yarrow, G. (1989). Privatization, an Economic Analysis. The MIT Press, Cambridge.

Vining, A.; Boardman, A, (2008). Public-private partnerships. Eight rules for Governments. Public Works Management \& Policy, Vol. 13, no. 2, pp. 149-161.

Viscusi, W.; Vernon, J.; Harrington, J. (1995). Economics of Regulation and Antitrust. $2^{\mathrm{a}}$ ed. The MIT Press, Cambridge.

Williamson, O. (1976). Franchising bidding for natural monopolies - in general and with respect to CATV. Bell Journal of Economics. Vol. 7, no. 1, pp. 73-104.

Williamson, O. (1985). The Economic Institutions of Capitalism: Firms, Markets and Relational Contracting. Free Press, New York.

Willig, R. (1978). Pareto-superior nonlinear outlay schedules. Bell Journal of Economics. Vol. 9, no. 1, pp. 56-69.

Zupan, M. (1989a). Cable franchise renewals: do incumbent firms behave opportunistically? Rand Journal of Economics. Vol. 20, no. 4, pp. 473-482.

Zupan, M. (1989b). The efficiency of franchise bidding schemes in the case of cable television: some systematic evidence. Journal of Law and Economics. Vol. 32, no. 2, pp. 401-445. 